\title{
„Unutrašnji emigrant”: političke ideje Milovana Đilasa 1954-1989*
}

\begin{abstract}
Stanić Veljko, „Unutrašnji emigrant”: političke ideje Milovana Đilasa 1954-1989 (,The Emigrant Within”: The Political Ideas of Milovan Djilas 1954-1989). „Poznańskie Studia Slawistyczne" 6. Poznań 2014. Publishing House Science and Innovate, pp. 243-260. ISBN 978-83-63795-51-1. ISSN 2084-3011.
\end{abstract}

The aim of this article is to examine the political ideas of Milovan Djilas (1911-1995) developed in his dissident period (1954-1989). Once a highly ranked communist and revolutionary of Tito's antifascist partisan army in the Second World War Yugoslavia, Milovan Djilas (1911-1995) became widely known as one of the most important dissident figures in Eastern Europe. A noted reformist since Tito-Stalin split in 1948 and political prisoner (1956-1961, 1962-1966), Djilas was deprived from all public activity in his country until the end of communist rule. Author of more than twenty books translated and published abroad, ranging from political analysis and memoirs to novels and shorts stories, Djilas never truly gave up the ideals of the young talented writer he was in the early 1930s when he joined the communists. Declaring himself a democratic socialist, it was in his dissident period that he formulated a specific form of political philosophy which included his criticism of communist ideology and Titoist authoritarian rule in Yugoslavia, but also wider thoughts on human condition, literature and philosophy in the $20^{\text {th }}$ century.

Keywords: Yugoslavia; Milovan Djilas; dissidence; political ideas; „the emigrant within”; communism

Sva velika dela u istoriji, nošena su velikim egzistencijalnim strastima.

Fransoa Fire

Milovan Đilas (1911-1995) je u istoriju zakoračio kao revolucionar nedugo nakon što je Oktobar 1917. proneo svoj plamen Evropom. On je revolucionarnoj strasti prineo svoje darove: idealizam mladog pisca, besprekornu posvećenost $\mathrm{i}$ jednodušnu odanost - $\mathrm{u}$ ilegali, na robiji, u ratu i revoluciji, i najzad

* Rad je nastao u okviru rada na projektu Istorija političkih ideja i institucija na Balkanu u 19. i 20. veku (br. 177011) Ministarstva prosvete, nauke i tehnološkog razvoja Republike Srbije. 
na vlasti. Pa ipak, Đilas bi ostao upamćen - ili zaboravljen - tek kao jedan od revolucionara sa čijim starenjem je starila i Revolucija, da njegov život nije postao žrtva onog désenchantement-a koji je pratio komunističku ideologiju tokom njenog celog trajanja. Presečen na pola, Đilasov život se mnogima činio kao izlomljena slika čije delove je nemoguće spojiti. Za neke jednostavno otpadnik i poraženi Titov opozicionar, Đilas je za druge bio ne samo važan svedok i pronicljivi posmatrač istorije, već i ugledni disident i dugogodišnji zatvorenik, politički mislilac i pisac obimnog i raznovrsnog opusa koji se kretao od politikoloških analiza, preko memoarskih dela do beletristike ${ }^{1}$.

Unutrašnji emigrant, Đilas je dugo bio pod senkom Titovog autoritarnog režima. Razapet između istorije i sećanja, njegov život još ni izbliza nije ispitan, a njegovo razuđeno delo zahteva ne manje slojevitu intelektualnu biografiju (Bartsch 1971, Hetzer 1980, Reinhartz 1981, Clissold 1983, Lustig 1989, Kalezić 1999). On stoji na početku disidentskog razdoblja u Titovoj Jugoslaviji, napušta ideju komunizma i razvija „liberalno-demokratska stajališta" (Spehnjak, Cipek 2007: 262-263). Koreni njegovog disidentstva uočavaju se u reformističkim idejama razvijanim od 1949. godine (Ivin 2005: 361-380). Među različitim prilazima njegovom delu, političke ideje u vreme disidentstva (1954-1989) ocrtavaju horizont intelektualne zrelosti u kome se sastaju njegova iskustva i zapitanosti; one u živim bojama osvetljavaju ne samo njegovu ličnu sudbinu, nego i stoleće u celini. Ovaj rad nastoji da pruži presek ključnih tačaka u pogledima Milovana Đilasa na politiku i svoju epohu, pružajući tako i sliku jednog samosvojnog disidentskog profila Istočne Evrope druge polovine 20. veka.

\section{Od revolucije do slobode}

Život Milovana Đilasa najlakše ćemo povezati sa stolećem u kome se odigrao. Dete 20. veka, Đilas pripada generaciji mladih intelektualaca koja je u svesni, politički život stupila ranih tridesetih godina. „Generacija koja nije imala izbor”, ona je često posmatrana kao radikalna, prevratnička, u Evropi čije je staro, liberalno lice bilo na izmaku. Ni Jugoslavija ni Đilas ne odstupaju

\footnotetext{
${ }^{1}$ Najbolji uvid u Đilasov razgranati opus, kao i u literaturu o njemu, dobija se u: Aranitović 2008 .
} 
od ovog pravila. Mladi literata iz Crne Gore, Đilas je student književnosti na Univerzitetu u Beogradu od 1929. godine. On već ima kratki komunistički staž kada je poslat na prvu robiju (1933-1936). Nakon toga, Đilas izbija u vrh Komunističke partije Jugoslavije i pred rat postaje član Politbiroa. Antifašista, revolucionar, on je jedan od lidera Titove partizanske vojske, ratni komandant, propagandista i diplomata. Nakon 1945, jedan od glavnih dužnosnika novog režima, Đilas je član „velike četvorke”: Tito, Ranković, Kardelj, Đilas.

Sve obećava jednu dugu i značajnu državnu karijeru. Đilas je na čelu važnih spoljnopolitičkih misija (cf. Edemskii 2011: 185-219; Miletić 2012: 291-312), a od još većeg značaja je njegov ideološki rad u Agitpropu CK KPJ. Međutim, Titov režim veoma rano svetu otkriva poražavajuću sliku sovjetskog internacionalizma. Sukob Staljin-Tito 1948. otvara poglavlje nacionalnog komunizma i unosi jeres „reformizma” u Istočnoj Evropi, što će potvrditi docniji primeri Poljske, Mađarske i Čehoslovačke (Furet 1995: 658-670). Nekada najbolji učenik Sovjetskog Saveza, Jugoslavija će, da bi ojačala svoju nezavisnu poziciju, već od 1949. preći u kritiku sovjetskog etatizma i birokratije.

U Jugoslaviji sledi talas liberalizacije čiji vrhunac označava Šesti konges KPJ 1952. Ali, dok se jugoslovenski maršal zadovoljava umerenim, taktičkim koracima, Đilas odlazi dalje. Njegov reformizam i težnja za ostvarenjem socijalističke demokratije ne staju na pitanju nacionalne nezavisnosti, već idu ka dubinskoj analizi sistema, kako sovjetskog, tako i jugoslovenskog. Đilas podvrgava kritici sistemske mane jugoslovenskog režima: birokratiju, partijsku državu, odsustvo slobode mišljenja. Kulminacija njegove kritike odvija se u jesen 1953. u člancima objavljivanim u „Borbi”, glasilu Saveza komunista Jugoslavije. Epilog je dalekosežan: na Trećem (vanrednom) plenumu CK SKJ u januaru 1954, Đilasove ideje su osuđene kao reformističke, a Đilas isključen sa svih državnih i partijskih funkcija. Tri meseca kasnije, Đilas svojevoljno istupa iz partije. Naredne gotovo četiri decenije on će u Jugoslaviji uživati ,ugled” glavnog političkog neprijatelja i dugogodišnjeg zatvorenika, a u međunarodnoj javnosti istaknutog kritičara komunizma, disidenta i pisca (cf. Stanić 2008: 251-278; Terzić 2010: 40-59)².

${ }^{2}$ U kasnijim godinama, Đilas će razviti plodnu saradnju sa liberalnim krugom srpske političke emigracije okupljene oko Saveza „Oslobođenje” i časopisa „Naša reč” u Londonu (cf. Radojević 2007: 118-135). 
Đilasova sudbina iz januara 1954. nije sasvim originalna; ona potvrđuje da su jeretici kao sastavni deo ideologije prisutni u svakoj generaciji. Tu nit možemo pratiti od početaka komunizma sa Oktobarskom revolucijom 1917 (Furet 1995: 165-211). Od raskida sa Staljinom preko reformizma ranih pedesetih godina prošlog veka, Đilas kao da obnavlja velike debate Druge internacionale i Staljinove opozicije. I zaista, Đilasovi kritičari nisu daleko od istine kada u njegovim idejama, iako više plodu intuicije i vlastitog političkog iskustva, nego doslednog teorijskog proučavanja, prepoznaju duh i senku jednog Bernštajna ${ }^{3}$.

Ono što, međutim, Đilasa izdvaja, nalazi se u njegovom ličnom razvoju. Đilas pripada onom tipu revolucionara koji je neodvojiv od ,suštinske iluzije" komunizma, o kojoj je ubedljivo pisao Fransoa Fire. Zasnovana na veri u istorijsku nužnost koja ,počiva na političkoj mašti modernog čoveka”, ova iluzija nije

nešto kao zabluda u donošenju suda, što se, pomoću iskustva, može uočiti, izmeriti, i ispraviti, nego više jedno psihološko ulaganje koje se može porediti sa ulaganjem u neko religijsko verovanje (...). Time se objašnjava zašto je mogla da nestane tek kroz nestajanje onoga čime je hranila svoju supstancu; kao vera u spasenje putem istorije, mogla je popustiti samo pred nekim radikalnim demantovanjem od strane istorije, koje bi oduzelo smisao radu na stvaranju te iluzije (Furet 1995: 10-11).

Idealista, u osnovi književnik čiji duh izvire iz patrijarhalnog etosa rodne Crne Gore, Đilas je specifičan mladi senzibilitet koji u komunizmu pronalazi raskošnu snagu, istovremeno jednostavnu i moćnu, jedinstvo nauke i morala. Neće je pokolebati ni ilegala, ni robija, ni rat, ni revolucija - već vlast. Željan da očuva Revoluciju, Đilas nakon 1948. teži da premosti jaz između nekadašnjih ideala i stvarnosti, nepremostivu razvalinu između faze revolucije i faze vlasti. Poraz njegovog reformizma potvrđuje ono što je još na vlasti naslutio - Titovo odvajanje od Staljina ima međunarodne posledice za komunistički pokret, ali ne i za komunizam kao ideologiju. I dok Staljinova smrt u martu 1953. u zemljama Istočne Evrope donosi izvesnu destaljinizaciju, Tito je kao pragmatičar od talenta već na putu da zauzda liberalizaciju u Jugoslaviji. Đilasov pad se zato odvija po poznatom boljševičkom modelu:

3 Priroda Đilasovog razlaza sa komunističkim vrhom na čelu sa Titom neke autore navodi na svojevrsnu erreur de perspective. Oni tako u Đilasu vide samo poraženog opozicionara, a ne i disidenta, neobično previđajući karakter kako Đilasovog ličnog angažmana tako i njegovog pisanog opusa u naredne četiri decenije (Miloradović 2011: 199-231). 
opšta osuda, izopštenje i nametnuto ćutanje. Istovremeno, Đilasov slučaj u Jugoslaviji, ali i šire u Istočnoj Evropi, ocrtava granice liberalizacije - ne može se dirati u suštinu vlasti i ideologije, jer to znači njihovo poricanje.

„Samo bivši komunisti imaju istovremeno unutrašnje iskustvo sistema i mogućnost da ga tumače spolja”, primećuje Fransoa Fire (Furet 1995: 724-725). Nesuđeni ideolog, Đilas će ironijom istorije, svetsku slavu steći kao kritičar komunizma. Đilasova pojava prethodi Saharovu i Solženjicinu, i moglo bi se reći da se pridružuje onom nizu intelektualaca, nemirnih svedoka i tumača 20. veka, koje Toni Džat smatra svojevrsnom Republic of Letters prošlog stoleća (Judt 2008: 14).

Đilasovo disidentstvo je izrazito političko - ono izvire iz politike i traje kroz nju, oivičeno suštinskim pitanjima kojima je posvećeno: ideološka dogma, partijski monopol, odsustvo pluralizma, društvena svojina, kulturne slobode. U nekoliko godina Đilas prelazi put od komuniste, preko reformiste, do disidenta - kritičara koji je na liberalnoj levici, sve dalje od neposrednog političkog angažmana. Godine provedene u zatvoru (1956-1961, 1962-1966) njegovo disidentstvo će samo produbiti i ojačati. Najzad, kod Đilasa kao jedan primarni egzistencijalni sloj postoji supstitut politike - to je svet književnosti, njegova duboka unutrašnja vokacija koja u ranoj mladosti prethodi komunističkom iskustvu.

Upravo na ravnoteži literature i politike Đilas kao disident stvara svoj intimni svet i kulturu otpora. Osamljen, okružen porodicom i nekolicinom prijatelja, Đilas je bez neposrednog uticaja u svojoj zemlji. Opredeljen je za ličnu, nenasilnu borbu, pisanje, davanje izjava stranoj štampi i nepokolebljiv u nameri da ostane u Jugoslaviji kao ,unutrašnji emigrant”. Nemamo pouzdanih saznanja koliko su Đilasova dela tajno čitana u zemlji. Ipak, važno je primetiti da se, za razliku od Istočne Evrope, disidentski pokret u Jugoslaviji, kao samoupravnoj i nesvrstanoj zemlji „trećeg puta”, formira dosta kasno, tek u poslednjoj deceniji njenog života (Đilas (ur.) 2009: 72, 379-382 ), a većina disidenata uplovljava u nacionalne teme (Spehnjak, Cipek 2007: 258-263).

\section{Protiv savršenog društva}

Pod gornjom sintagmom mogao bi se sažeti smisao Đilasovog disidentskog angažmana. U njemu je sadržana otrežnjujuća, antiutopijska poruka: 
nema savršenog poretka koji bi uniformisao tako složen i raznovrstan svet; nema univerzalne ideje koja bi ukrotila granice čovekovog duha. Đilasove političke ideje nakon raskida sa komunizmom zasnovane su na širim humanističkim vrednostima, individualizmu, slobodi mišljenja, zalaganju za prava čoveka, ali i na težnji ka socijalnoj pravdi i ukupnom materijalnom i moralnom prosvećivanju.

Korpus Đilasovih političkih ideja određen je najpre kritikom komunizma kao ideologije i sistema. Ona je najpreglednije izložena u poznatom Đilasovom klasiku Novoj klasi, objavljenom u SAD-u 1957. Nastavak njegovih kritičkih ideja razvijanih dok je još bio na vlasti, „Nova klasa” ima snažnu recepciju u svetu. U vremenu hladnoratovskog ideološkog sukoba, ona razobličava komunistički sistem iznutra i oduzima mu moralni kapital. Đilasovo štivo pripada antitotalitarnom intelektualnom kontekstu koji se uobličava zajedno sa konturama Hladnog rata od poznih četrdesetih godina (cf. Judt 2010: 197-225). U tom svetlu, Nova klasa se u intelektualnoj i akademskoj javnosti Zapada pridružuje raznovrsnom nizu dela poput Kestlerovog Pomračenja u podne, Orvelove 1984, Kamijevog Pobunjenog čoveka, ali i Izvora totalitarizma Hane Arent, Zarobljenog uma Česlava Miloša ili Opijuma intelektualaca Rejmona Arona. Dodatnu pažnju u javnosti izaziva saznanje da je Đilas donedavni visoki komunistički lider, a sadašnji politički zatvorenik Titove Jugoslavije (Rubinstein, Roffe Wike 1958: 774-787).

Za Đilasa nema sumnje: „Herojsko doba komunizma je prošlo. Epoha njegovih velikih vođa se završila. Nastaje epoha praktičara. Nova klasa je stvorena. Ona je na vrhuncu snage i bogatstva, ali bez novih ideja. Ona više nema šta svetu da kaže. Ostalo je još samo da ona bude objašnjena" (Đilas 1990: 56). U ulozi tumača, Đilas u partijskoj birokratiji više ne vidi samo štetnu pojavu, već čitavu novu klasu koju stvara komunistička partija. Komunizam ne donosi idealno, besklasno društvo, već učvršćuje totalitarnu vladavinu jedne partije. Koreni sežu daleko. Oni su ne samo u utopijskoj ideji kao viziji sveta, već u njenom spoju sa naučnim objašnjenjem koje dobija izraz u Marksovom učenju. Komunistička revolucija koncipirana i ostvarena prema Lenjinovim zamislima, u rukama jedne centralističke komunističke partije, monopolizuje moć i ostvaruje totalnu kontrolu nad društvom u čijoj službi su i teror i ideološki nadzor. Pod velom državne ili društvene svojine, partija gospodari sredstvima za proizvodnju i sprovodi industrijalizaciju. Ali, ona ne može da napusti koncept ideološke privrede, 
niti da dozvoli političke i kulturne slobode, a da se ne odrekne političkog monopola. Raskorak između zamisli revolucije i njenih ostvarenja je dubok: „Revolucija najapsolutnijih i najidealnijih ideala, najlepšeg heroizma i najgigantskijih naprezanja, komunistička revolucija seje i najveće i najdugotrajnije iluzije" (Đilas 1990: 35).

Iako se sam pojam ,nove klase” sreće i ranije, kod tako različitih duhova kakvi su Lenjin i Berđajev, Đilas joj prvi posvećuje knjigu, uz to britku i reljefnu kritiku kao prvorazredno iskustvo bivšeg komuniste, da bi odmah potom sam termin ušao u široku upotrebu. Istovremeno istorijsko svedočanstvo sazdano uglavnom na jugoslovenskom primeru, ali i sociološka analiza širih pretenzija, Nova klasa je u središtu mnogih političkih i stručnih debata. Među njenim glavnim doprinosima je pomeranje poznate kritike Lava Trockog upućene sovjetskom lideru. Dok je Staljinov oponent u sovjetskoj birokratiji video „kastu”, deformaciju izvornog, Lenjinovog sistema, za Đilasa je nezamislivo da se Staljin sagledava nezavisno od lidera Oktobra i temelja koje je on postavio. Gospodarenje nad svojinom je posledica totalne vlasti koja se osvaja komunističkom revolucijom; ukoliko se ona demontira, nestaje i politički monopol komunističke partije bez koje nema nove klase (cf. Lustig 1989: 112-147; Saccarelli 2008: 127). Rejmon Aron u svojim predavanjima na Sorboni „Novu klasu” naziva „makijavelističkom kritikom” komunističkih režima (Aron 1997: 130-131). Ralf Darendorf s pravom primećuje da Đilas primenjuje marksističku analizu komunističkog društva i u tome vidi posebnost „Nove klase” čiji sadržaj poredi sa delima Renera, Šmpetera, Barnama i drugih. Darendorf ističe da Đilas nedvosmisleno odbacuje mišljenja o partijskim birokratama kao ,prelaznom stratumu” koji bi se podveo pod ime ,inteligencije”, već formuliše svoje viđenje nove klase zasnovane na posedovanju svojine i moći, koncepta koji je i sam Darendorf razvijao. Istovremeno, Đilas novu klasu identifikuje na osnovu kolektivne svojine, a ne više privatne koju je u teoriji klasa nudio Marks (Dahrendorf 1959: 82-84). U zapadnoj intelektualnoj javnosti, Đilasovim pogledima na novu klasu, posebno preko koncepta „kolektivnog aparata aproprijacije”, bliski su Kornelijus Kastorijadis i Klod Lefor, i sami komunistički disidenti i pokretači časopisa „Socialisme ou barbarie” 1948 (Nove 1984: 597; Lefort 1986: 67-68, 71-72, 91, 118.).

Analiza evoluiranja partijske birokratije u novu klasu je neugodno oružje po režime Istočne Evrope, i još više za sovjetsku kontrolu ovih zemalja. 
Nova klasa postaje neizbežni deo disidentske literature, sa brojnim izdanjima u svetu (šezdeset jezika i tri miliona primeraka), uključujući i samizdate. $\mathrm{Na}$ Đilasovom tragu u Istočnoj Evropi su Jacek Kuronj i Karol Modzelevski u Poljskoj, kao i Ota Šik u Čehoslovačkoj (Voslensky 1984: 7-8). Sovjetski disident Mihail Voslenski 1980. objavljuje temeljnu studiju Nomenklatura: anatomija sovjetske vladajuće klase, sa predgovorom Milovana Đilasa (cf. Voslensky 1984). Osim toga, Đilasov koncept nove klase, kao i ukupni pogledi na Sovjetski Savez i Staljina imaju brojne dodirne tačke sa „totalitarnom paradigmom" u pretežno američkoj sovjetologiji pedesetih i šezdesetih godina prošlog veka. Usredsređenost na prirodu režima, na fenomene moći, ideologije i terora, Đilasa čini prisutnim među autorima kakvi su Fejnsod, Gurijan, Karl Fridrih, Šapiro, Mendel, Ulam i drugi (Cohen 1977: 3-11). Najzad, Đilasa i danas srećemo u akademskim studijama staljinizma i Sovjetskog Saveza uopšte. Tako, na primer, jedan od vodećih stručnjaka u ovom domenu Šila Ficpatrik smatra Đilasov doprinos klasičnim, iako ga modifikuje i preko nove klase kao privilegovanog sloja ispituje socijalnu mobilnost radničke klase (Fitzpatrick 2000: 39).

Nakon izlaska sa druge robije, Đilas će uobličiti još jednu zapaženu studiju Nesavršeno društvo: i dalje od „Nove klase” (1969). Pripremana još u zatvoru, ona u mešovitoj formi meditativne i memoarske proze prožete politikološkim opservacijama dovršava Đilasov raskid sa marksizmom. Trajni otklon od ideološkog pogleda na svet, Nesavršeno društvo Đilasa okreće širim literarnim i filozofskim duhovnim stremljenjima. Prema jugoslovenskom disidentu, komunizam više ne može pretendovati na status svetske ideologije; sa njegovom fragmentacijom nastupa i krah marksizma čija dogmatska univerzalnost nije kompatibilna sa kompleksnostima u kojima se svet i njegov ekonomski, društveni i tehnološki razvoj kreću. Nastupa „sumrak ideologija”, smatra Đilas, a u prvom redu ima u vidu komunizam kao svetsku ideologiju:

Moćan, nesavladiv i nepobediv kao revolucionarni pokret i organizacija nasilja, komunizam se pokazuje slabim u normalnim uslovima i ljudskim, slobodnim odnosima. Zabranjujući druge ideje i razarajući sve druge oblike sem vlastitih - komunizam je potkopao i samoga sebe (...). Budući pretežno vlast, i to vlast naročite vrste - vlast prisiljena istorijskim okolnostima da obavi industrijalizaciju, komunizam postaje nemoćan i suvišan čim obavi tu svoju ulogu. Grupe i ideje koje se rađaju u društvu koje je on sazdao, pa i u njemu samom, mogu kraće ili duže biti komunističke po imenu, ali po svojoj suštini one prestaju 
da to budu u onoj meri u kojoj postaju trpeljive prema drugim gledanjima i grupama. Komunizam ne gubi istorijske bitke, nego bitku s istorijom, uprkos tome ili baš zbog toga što je verovao da je spoznao njene zakone (Đilas 1970: 130).

\section{Spectateur engagé}

Dok je u Novoj klasi i Nesavršenom društvu uobličio svoje temeljne poglede na komunizam i probleme savremenog sveta, Đilas je razvio aktivnost plodnog političkog komentatora i stekao ugled jednog od vodećih stručnjaka za komunizam koji se oglašava u međunarodnoj štampi i časopisima. Piše za „Le Monde”, „Le Figaro”, „Der Spiegel”, „Die Welt”, „The New York Times”, „The Washington Post”, „The Times” „Encounter”, „Survey”, „Foreign Affairs” „International Herald Tribune”, „Corriere della Sera” i brojne druge. Sa Solženjicinom, Saharovom i Brodskim uređuje časopis „Continent”. Možda mu, pomalo neobično, najbolje pristaje epitet ,,angažovanog posmatrača" - zabranjen u zemlji, on je svojim radovima prisutan u međunarodnoj političkoj i akademskoj areni. Robert Taker ga ubraja $\mathrm{u}$ nonconstituted leaders, tj. one intelektualne figure, neretko disidente, koje su ,protiv shvatanja koje politiku svodi na borbu za vlast i vršenje vlasti”, i koje su ,u svom političkom delovanju pokazale sposobnost... da se izdignu iznad ličnih ili partijskih shvatanja moći” (Tucker 1981: 7).

U razmišljanjima o komunističkoj ideji Đilas se neretko vraćao na kanonske figure. Istorija vođa neodvojiva je od pokreta i ideologije. U njihovom portretisanju, spajalo se Đilasovo istorijsko i teorijsko poznavanje komunizma sa literarnim i psihološkim uvidima. „Apsolutni i realistički revolucionar”, piše Đilas, „Lenjin je i nepomirljivi i zaneti dogmatik”. U njegovoj koncepciji boljševičke partije, koreni su totalitarizma. Iako je nastavljač Marksa, on je to samo u revolucionarnoj, a ne humanističkoj strani Marksovog nasleđa. ,Zanet dogmom i revolucijom, Lenjin nije bio kadar da shvati kritiku nemačke komunistkinje Roze Luksemburg - da bez ličnih sloboda nije mogućno nikakvo demokratsko, pa samim tim ni socijalističko društvo". Marksovoj direktnoj vlasti masa, Lenjin će suprotstaviti monopol centralističke organizovane partije. Umesto odumiranja države, „nestvarna i neostvariva diktatura proletarijata je postpuno degenerisala u diktaturu partijske birokratije". Veliki lider prve komunističke revolucije, Lenjin je 
čuvar propalog dela: „Njegova tragedija je istorijska - njegovo delo se preobrazilo u svoju suprotnost, a njegova verovanja u obmane i samoobmane" (Đilas 1994: 224-229, 247-249).

Ipak, tvorac lenjinizma kao zatvorenog ideološkog sistema, jednostavnog i prilagođenog neposrednim potrebama partijske vlasti je - Staljin. Na prvi pogled neobično, Đilas Staljinu kao marksisti daje prednost nad njegovim velikim suparnicima Trockim, Buharinom, Zinovjevom i drugima. Jer, Đilasov uvid u vezi je sa sovjetskom stvarnošću nakon Lenjinove smrti:

Staljin nije pobedio zbog toga što je ,izopačavao" maksizam, nego baš zbog toga što ga je ostvarivao... Trocki se permanentno razbacivao paradoksima i konstrukcijama svetske revolucije, Buharin se udubljivao u dogmatske tananosti... dok je Staljin svojim obrazlaganjima ,narednih zadataka” poistovećivao opstanak i privilegije preobražene i novonastale partijske birokratije s industrijalizacijom i snaženjem Rusije (Đilas 1994: 234-235).

Staljin je najbolje osetio kretanje „totalne vlasti” koju je ostvario Lenjin. Zato Đilas smatra da „nije Staljin izumeo totalitarnu partijsku birokratiju nego je ona u njemu našla svog vođu" (Đilas 1994: 239). Staljinov teror i njegova „demonska” priroda nerazlučiva je „od ideje i pokreta”. Veliki naslednik, Staljin je i veliki realizator. On ,poistovećuje vlast, državu i vlastitu ličnost. Da li je moglo biti drukčije - u svetu konačnih istina, s verom u besklasno, savršeno društvo? Sam cilj je posvetio sredstvo", zaključuje Đilas (Đilas 1994: 243).

Sa procesom destaljinizacije u vreme Hladnog rata, komunistička ideja ne gubi na snazi u svetu. Naprotiv, ona osvaja i nove prostore, a ostaje moćna i u zapadnoj intelektualnoj javnosti (Furet 1995: 784-801). Otklon od Staljina najpre vodi ka Lenjinu, a potom ka Marksu. Ove operacije Đilas ne vidi drugačije nego kao deo jedne ideološke opsene. Učenja tzv. marksista humanista, orijentisanih ka mladom Marksu i posebno njegovoj teoriji otuđenja, svedoče o snazi revolucionarnih iluzija. Đilas zato ironično primećuje: „Doista, mnoge su se stvari promenile od Marksovog vremena, i s pravom se možemo zapitati: nije li današnji let u teoriju otuđenja takođe pokazatelj otuđenja od stvarnosti i sopstvenog razuma?" (Djilas 1975: 404). Marksizmu je imanentna promena sveta, on se ne može svesti na „čisti”, jer bi bio ,poricanje samog sebe" (Đilas 1994: 307). U ovom smislu, Đilas deli dosta toga sa Kolakovskim; oni se susreću u napuštanju ,izvornog Marksa” - staljinizam 
nije greška, nego krajnja konsekvenca marksizma (Đilas 1994: 271). Kolakovski s pravom za Đilasa kaže da se on više ne može smatrati ni revizionistom ni marksistom: „Đilas je potpuno napustio utopijski način mišljenja, i mnogo puta ukazao na veze izvorne marksističke doktrine i njene političke realizacije u vidu birokratskog despotizma" (Kolakowsky 1978: 478).

U „Novoj levici” Đilas vidi samo novi pokušaj ostvarivanja starog ideala: „Nova levica” je jedino obećavala da će biti vernija idealu nego što je to bila stara levica, ali sam ideal, tj. savršeno (komunističko, anarhističko) društvo ostao je neizmenjen" (Đilas 1994: 275). Liberalni komunizam ne postoji, jer se zatvoreni ideološki sistem ne može reformisati. Značaj jeretika u komunizmu delotvoran je jedino ukoliko svojom

kritikom ukazuju na izlaze iz začaranog kruga, a ne kukaju zbog izneveravanja dogme i odsustva egalitarstva... Zbog toga su levi časopisi i levi profesori u Jugoslaviji jedino kadri da potvrde svoju jalovost, uprkos svoj svojoj učenosti i relativnoj trpeljivosti režima prema njima (...). Ali komunizam je neotporan, neodbranjiv prema kritici koja ga objašnjava bez predrasuda i napipava mogućne izlaze iz njega. Zbog toga su Solženjicin u Rusiji i Kolakovski u Poljskoj neuništivi i nepobedivi, uprkos svojoj usamljenosti: njihove kritike, mada različite, istovremeno su i vizije, ali ne nekog tuđeg i nestvarnog društva, nego onog koje se začinje i razvija na tlu samog komunizma (Đilas 1994: 317).

Na međunarodnoj areni primer Jugoslavije pokazuje da nacionalni komunizam ne prelazi granice komunizma kao ideologije. Komunizam se realizuje, u smislu ostvarivanja moći, u nacionalnom okviru, i zato se uprkos proglašenom internacionalizmu on deli na nacionalne komunizme. Ova fragmentacija nepovoljno utiče na solidarnost unutar komunističkog pokreta. Tako, na primer, držanje Jugoslavije u vreme Mađarske krize 1956. pokazuje ograničenja njene nezavisne politike. Istovremeno, kriza sovjetskog imperijalizma manifestuje se kao kriza ideologije, a „oluja u Istočnoj Evropi” otvara novo poglavlje u istoriji čovečanstva (Djilas 1956: 3-6; Kovačević 2012: 103-125). Čehoslovačka 1968. godine nudi novi prostor za razmišljanje u ovom pravcu (Djilas 1968: 368-371).

I odnos SSSR i Kine Đilas sagledava u ravni geopolitike. Iza raspri o ideološkoj suprematiji i ispravnom tumačenju „marksizma-lenjinizma", krije se borba za hegemonijom. Kineska revolucija je, po ugle$\mathrm{du}$ na rusku, promenila geopolitičku sliku sveta. Iako Peking pretenduje da postane „revolucionarno-dogmatski” centar naspram Moskve kao 
„birokratsko-konzervativnog”, Đilas smatra da je Kina preslaba da se nametne kao model komunističke revolucije u manje razvijenim zemljama (Djilas 1975: 41). Nakon Mao Cedunga, ona će se verovatno otvarati reformama i pronalaziti svoje drevne, „nacionalne struje” (Djilas 1975: 387-395). U slučaju Vijetnama uspeh komunističke revolucije povezane sa borbom za nacionalno oslobođenje ne predstavlja novost. Đilas ga povezuje sa iskustvom Jugoslavije u Drugom svetskom ratu (Djilas 1975: 376-382).

Zaokružujući u jednom od poslednjih osvrta svoje poglede na komunizam, Đilas je isticao da je krah komunizma rezultat unutrašnjeg raspada, povlačenja nove klase sa istorijske scene i samorazaranja čitave jedne epohe i ideje:

Komunizam je porazio samog sebe - raspao se iznutra na najružniji, na sramotni i bespovratni način (...). Utopija nije, niti je mogla, biti ostvarena - od ideje je ostalo njeno metodično, „naučno”, totalno nasilje. Jer, utopija nije sama po sebi zlo - naprotiv, ona je inspirativna: zlo je utopija kao mogućna vlast, u čemu i jeste realnost Marksovog učenja (Đilas 1994: 320-321).

\section{Jugoslavija, jedna nepomična revolucija}

Bez prilike da utiče na političke tokove u Jugoslaviji, Đilas, ipak, glavni deo svog opusa posvećuje njenim problemima. U političkim analizama najviše se bavi komunističkom ideologijom, nacionalizmom, Titovom ličnom vlašću, nedostatkom političkih i ličnih sloboda, dezintegracionim procesima. Nakon izlaska iz zatvora, Đilas je svedok prelomnih šezdesetih godina, pozdravlja pokušaje liberalnih reformi, ali i kritikuje njihovo zaustavljanje početkom sledeće decenije. Đilasove ocene vremenom postaju zloslutnije i anticipiraju urušavanje komunizma i tragični slom države.

Iako nije osporavao njegov istorijski značaj, Đilas je podvrgavao kritici Titovo shvatanje države kao lične vlasti. Veliki otpadnik od Staljina, Tito je u očima zapadne političke javnosti uživao relativnu naklonost. Ipak, Jugoslavija je samo prividno mogla da ponudi ,socijalizam sa ljudskim licem”. Tito je odsudno iskoristio vreme destaljinizacije u svetu kako bi učvrstio jedan trpeljiviji režim, sa neprikosnovenim dogmama o revoluciji, samoupravljanju i politici nesvrstanosti. U intervjuu nemačkom časopisu „Der Spiegel” 1980. Đilas kaže: 
Ako Vi posmatrate iz blizine politički sistem, jednopartijski sistem, sa njegovom moćnom tajnom policijom, koja kontroliše ceo život, sa svojim zahtevom za ideološku isključivost, sa svojim kultom - ne samo kultom ličnosti, kultom revolucije, kultom ideologije - onda, naime, mislim da razlika sa istočno-evropskim zemljama postoji samo u privrednom sistemu, i da u kulturi ima više tolerancije (Tošić 2003: 142).

Priroda Titove vlasti bila je u njegovom sovjetskom iskustvu, što je istovremeno ograničavalo reformske iskorake unutar partije, posebno onaj srpskog „liberalnog” rukovodstva u periodu 1968-1972, koje je u bitnim crtama bilo na nekadašnjem Đilasovom tragu:

Tito je, boraveći u Sovjetskom Savezu za vreme čistki i u jugoslovenskoj partiji, shvatio da ideologija pre svega treba da služi institucijama, partiji i vlasti: nemenjanjem ideologije vlast dobija stabilnost i monolitnost. Tito je rezonovao: treba kroz Kominternu slušati Staljina i sovjetske vlasti kao realnu silu, ali, potajno, ne smetati s uma i interese svoje partije i svoje vlasti, ili - kako bi on to rekao - svog naroda i svoje zemlje (Đilas 1994: 329).

Višenacionalni karakter Jugoslavije i njegov dinamizam predstavljali su jedno od glavnih pitanja Đilasove analize. U pariskom listu „Le Monde” od 20. decembra 1971, Đilas je odbacivao zvanični stav po kojem je nacionalno pitanje u Jugoslaviji bilo rešeno izgrađivanjem socijalističkih odnosa, jer komunisti „nisu učinili ništa ili... su učinili teške pogreške”. Ustavne promene u SFRJ proizvele su ,zahteve nacionalnih partijskih birokratija, republičkih vrhuški, zahteve koji uglavnom dolaze iz iracionalnog”. Zahtevi Hrvatskog proleća vodili su, po Đilasu, u tradicionalni nacionalizam: „Hrvatska je klizila u stvarnosti ka separatizmu i autoritarnom nacionalizmu" (Tošić 2003: 125-130).

Osnova nacionalnih problema u Jugoslaviji nije ležala samo u teškoj prošlosti, već su problemi dodatno evoluirali zahvaljujući dogmatskoj partijskoj politici. Taj viši stupanj Đilas je odredio kao birokratski nacionalizam, pišući dosledno o njemu kao o generatoru jugoslovenske krize. Iste 1971. godine, Đilas je zapisao:

Partijska birokratija ne evoluira, nego se raspada i najvećim delom preobražava u nove autoritativne strukture... Jugoslavija je slobodnija, ali i nestabilnija: prete nezaboravljene pomame i nesreće iz nacističke najezde i građanskog rata... Raspadanje partijskog monopolitizma oslobađa ljude i narode sivila i strave ideološkog i političkog totalitarizma. Ali taj raspad ne donosi automatski slobode za kojom narodi i ljudi čeznu. Za bekstvo u šovinizam, u nacionalističku ideologiju dovoljno je osloniti se na iracionalne impulse i mitsko nasleđe - izlazi iz birokratskog nacionalima zahtevaju utoliko teže i svesnije napore. Pred svetom je pojava koja pruža nove mogućnosti, ali i opasnosti (Đilas 1994: 286-287). 
Iste redove, sa tragičnim bilansom, Đilas je mogao potpisati i dvadeset godina kasnije.

Označujući Jugoslaviju kao „nepomičnu revoluciju”, Đilas je podvlačio duh novog talasa ideološke indoktrinacije sedamdesetih godina nakon pada hrvatskog i srpskog liberalnog rukovodstva. „Jugoslavija živi i živeće još dugo vremena”, pisao je u francuskom listu „Preuves” 1974. godine, „u dogmatizmu, čas ojačanom, čas ublaženijem. Ona nije stvorila demokratske ustanove. Građanski rat je zaustavljen, nije ugušen. I to će trajati. Nestanak Tita sa političke pozornice promeniće dinamizam središta. On neće ponuditi zbog toga osnove za promenu ustanovljenog poretka" (Tošić 2003: 131-134).

Đilas nije bio siguran u izvesnost reforme sistema, iako nije odricao da je moguća. Kritikovao je Ustav iz 1974. kao sredstvo kojim se potvrđivao partijski monopol nad društvom i izazivale neposredne podele i ,raslojavanja" jugoslovenskog društva. Zbog prirode autoritarnog poretka i nepostojanja organizovanog opozicionog delovanja, jedina prilika je bila reformski kurs iz liberalnijih krugova partije. „Ukoliko u idućim godinama iz samog sistema, odnosno iz vladajuće partije, ne dođe do nedvosmislenog i korenitog reformskog pokreta, ceo sistem nezaustavljivo srlja u kataklizmične socijalne i nacionalne nemire", pisao je 1983. godine (Tošić 2003: 180-183).

Dve godine kasnije, njegova predviđanja bila su gorka:

\begin{abstract}
Nacije se samo mogu dalje osamostaljivati. Jugoslovenska zajednica će se ili združiti na jednom nivou, konfederativnom i demokratskom nivou, ili slabiti i izlagati društvo i narod tragičnim i spoljnim neizvesnostima. Put od birokratskih nacionalizama vodi $u$ haos i rasulo ili u konstituisanje na novim društvenim osnovama, u novim, slobodnijim nacionalnim odnosima (...). Jugoslavija će se obnoviti kao demokratska konfederacija ili raspasti i biti raskomadana. Verujem u ovo prvo, premda danas ne postoje organizovane snage koje bi se tog životnog, istorijskog zadatka prihvatile (Tošić 2003: 189-191).
\end{abstract}

Prevaga nacionalnog pitanja preko kojeg su se odslikavali ekonomski, socijalni, verski i kulturni aspekti jugoslovenske krize sredinom osamdesetih, bila je, prema Đilasu, neumoljiva posledica višedecenijskog odsustva političkih sloboda koje bi u skladu sa novim okolnostima rešavale i nacionalne probleme.

Raspad Jugoslavije u ratu, po Đilasu, nije bio neminovnost. Ipak, postojali su nesumnjivi unutrašnji razlozi koji su sužavali mogućnost mirnog razlaza ili preuređenja jugoslovenske federacije: 
Nikad nisam verovao da će posledica sloma komunizma biti građanski ratovi: komunizam i nije oboren građanskim ratom (...). U revolucijama su potučeni nacionalizmi, ali oni lako buknu elementarnom silinom ukoliko se nisu u društvu razvili određeni odnosi: demokratske institucije, slobodna ekonomija, srednja klasa (Đilas 1994: 330-331).

\section{Zaključak}

Političke ideje Milovana Đilasa u vreme njegovog disidentstva ideje su političkog oponenta i kritičara u jednom autoritarnom poretku. One se moraju sagledavati u kontekstu vremena u kome nastaju od ranih pedesetih godina prošlog veka, sa značajem i ulogom koje imaju kako u Jugoslaviji tako i svetu, pa sve do kraja epohe komunizma 1989. U njihovoj analizi, međutim, neophodna je i svest o pređenom putu; kraj Hladnog rata pokopava komunističke iluzije na način u mnogo čemu anticipiran u stavovima istočnoevropskih disidenata među kojima Đilas zauzima istaknuto mesto.

Glavni Titov disident, Đilas ne gradi zaokružen sistem političkih ideja niti nudi zasebna, eksperimentalna rešenja. Naprotiv, zasnivajući kritiku komunističkog režima i ideologije iznutra, oslobađajući se nekadašnjeg iskustva, on se zalaže za demokratizaciju, uvođenje višestranačja, poštovanje ličnih i građanskih sloboda. Ideološki gledano, Đilas se pozicionira na liberalnoj levici, a izjašnjava kao demokratski socijalista. Odlučan na ličnu, nenasilnu borbu, publicistički i književni rad, Đilas je tokom gotovo četiri decenije izložen izolaciji i strogom nadzoru, a od toga devet godina u zatvoru kao politički zatvorenik.

Koreni njegovog disidentstva, a samim tim i političkih ideja za koje se zalagao, eshatološke su prirode. Đilasova vezanost za komunizam u revolucionarnom periodu pruža odličan primer za proučavanje „verničke” psihologije u komunizmu. Tako i njegovo disidentstvo, pogledi na komunizam kao ideologiju i sistem, uvidi u međunarodnu politiku i razvoj jugoslovenskog socijalizma, ne mogu se razumeti bez proučavanja intelektualne biografije Milovana Đilasa. U uočavanju promena i evolucije, u markiranju uticaja i različitih doba jednog pojedinačnog života, otkriva se pravi, dublji smisao čovekove egzistencije. Ne samo čovek dela, već i misli i pera, Đilas za sobom ostavlja još uvek nedovoljno pročitano i proučeno delo. 
Dometi Đilasovog disidentstva su, takođe, daleko od konsenzusa. Iako je razvoj Titove Jugoslavije i njen raspad u građanskom i međuetničkom ratu u mnogo čemu potvrdio Đilasove ocene - a to bi se s punim pravom moglo reći i za komunističku ideologiju u celini, na svetskoj pozornici Đilas je disident bez sledbenika. Iako ponovo prisutan u jugoslovenskoj javnosti od 1989, simbolički gledano Đilas ostaje disident do kraja svog života, protivan nacionalističkim sukobima, naklonjen jugoslovenskoj celini i mirnoj demokratskoj tranziciji. Ako sa stolećem koje je iza nas neminovno odlaze i ljudi i dela neraskidivo utkani u njegove borbe, mogli bismo utvrditi da od disidenata, ipak, nešto i ostaje: racionalno sagledavanje istorijskih i političkih pojava, otpor jednoumlju, individualizam i sklonost ka literarnom i filozofskom promišljanju sveta i čovekove sudbine.

\section{Literatura}

Aranitović D., 2008, Milovan Đilas. Bibliografija sa hronologijom života i rada, Beograd.

Aron R., 1997, Demokratija i totalitarizam, Sremski Karlovci-Novi Sad.

Bartsch G., 1971, Milovan Djilas oder die Selbstbehauptung des Menschen, München.

Clissold S., 1983, Djilas. The Progress of a Revolutionary, Hounslow.

Cohen S.F., 1977, Bolshevism and Stalinism, u: Stalinism. Essays in Historical Interpretation, ur. R.C. Tucker, New York, str. 3-29.

Dahrendorf R., 1959, Class and Class Conflict in Industrial Society, Stanford.

Djilas M., 1956, The Storm in Eastern Europe, „The New Leader” 19.11., str. 3-6.

Djilas M., 1968, The Unquenchable Fires of Czechoslovakia, „The Central European Federalist" br. 8-12, str. 368-371.

Đilas M., 1969, Nesavršeno društvo: i dalje od Nove klase, London.

Djilas M., 1975, Parts of a Lifetime, ur. M. Milenkovitch, D. Milenkovitch, New York.

Đilas M., 1990, Nova klasa, Beograd.

Đilas M., 1994, Pad nove klase. Povest o samorazaranju komunizma, Beograd.

Đilas A. (ur.), 2009, Iz emigracije. Izabrani eseji, članci, intervjui i dokumenti 1980-1990 , Beograd.

Edemskii A., 2011, The Role of Milovan Djilas in Soviet-Yugoslav Relations 1944-1954, $\mathrm{u}$ : The Balkans in the Cold War. Balkan Federations, Cominform, Yugoslav-Soviet Conflict, ur. V.G. Pavlović, Belgrade, str. 185-219.

Fitzpatrick S., 2000, Ascribing Class: The Construction of Social Identity in Soviet Russia, u: Stalinism: New Directions, ur. S. Fitzpatrick, London. 
Furet F., 1995, Le passé d'une illusion. Essai sur l'idée communiste au xxe siècle, Paris. Hetzer A., 1980, Spontanität und Gewalt. Milovan Djilas 'historische Prosa 1930-1970, Göttingen.

Ivin D., 2005, Pojava disidenata u socijalističkoj Jugoslaviji, u: Dijalog povjesničaraistoričara 9, ur. H.G. Fleck, I. Graovac, Zagreb, str. 361-380.

Judt T., 2008, Reappraisals. Reflections on the Forgotten Twentieth Century, New York. Judt T., 2010, Postwar. A History of Europe since 1945, London.

Kalezić V., 1999, Đilas, suprotnosti pisca i ideologa, Beograd.

Kolakowsky L., 1978, Main Currents of Marxism, t. 3, The Breakdown, Oxford.

Kovačević K., 2012, Milovan Đilas i Mađarska kriza 1956. godine, „Istorijski zapisi” br. 1-2, god. LXXXV, str. 103-125.

Lefort C., 1986, The Political Forms of Modern Society. Bureaucracy, Democracy, Totalitarianism, Cambridge-Massachusetts.

Lustig M., 1989, Trotsky and Djilas. Critics of Communist Bureaucracy, New York.

Miletić A.V., 2012, Spoljnopolitička delatnost Milovana Đilasa 1944-1953, u: Jugoslovenska diplomatija 1945-1961, ur. S. Selinić, Beograd.

Miloradović G., 2011, Ljudi na strateškim mestima. Uzroci, posledice i smisao sukoba Josipa Broza Tita i Milovana Đilasa na Trećem (vanrednom) plenumu CK SKJ 1954. godine, u: Tito: viđenja i tumačenja, ur. O. Manojlović-Pintar, Beograd.

Nove A. [A. Yakovlevich Novakovsky], 1984, Is There a Ruling Class in the USSR?, u: Classes, Power, and Conflict. Classical and Contemporary Debates, ur. A. Giddens, D. Held, London.

Radojević M., 2007, Milovan Đilas i srpska politička emigracija 1954-1995, „Tokovi istorije" br. 4, str. 118-135.

Reinhartz D., 1981, Milovan Djilas: A Revolutionary As a Writer, New York.

Rubinstein A, Roffe Wike J., 1958, The Djilas Heresy: Its Beginning and Development, „The Western Political Quarterly” br. 4, t. 11, str. 774-787.

Saccarelli E., 2008, Gramsci and Trotsky in The Shadow of Stalinism. The Political Theory and Practice of Opposition, London.

Spehnjak K., Cipek T., 2007, Disidenti, opozicija i otpor: Hrvatska i Jugoslavija 1945-1990, „Časopis za suvremenu povijest” br. 2, god. 39, str. 255-297.

Stanić V., 2008, Milovan Đilas 1953/54: između revolucije i slobode, „Tokovi istorije” br. 3-4, str. 251-278.

Terzić M., 2010, Ništa nije radio već sedio i pisao - slučaj Milovana Đilasa u JNA 1954, „Vojno-istorijski glasnik” br. 2, str. 40-59.

Tošić D., 2003, Ko je Milovan Đilas. Disidentstvo 1953-1995, Beograd.

Tucker R.C., 1981, Politics as Leadership, Missouri-London.

Voslensky M., 1984, Nomenklatura. Anatomy of the Soviet Ruling Class, London. 
